\title{
Dávid Réka Anna
}

\section{Sorsváltozatok a jelenlétben. Az újrakezdés lehetôségei Tóth Barnabás Akik maradtak és Török Ferenc 1945 címú filmjében}

\begin{abstract}
Absztrakt
Jelen tanulmány az emlékezet és a holokauszt kapcsolatát, valamint a magyar posztholokauszt, vagyis a második világháború utáni idôszak mozgóképes megjelenítését vizsgálja az Akik maradtak (2019) és az 1945 (2017) címú filmekben. A vizsgálat elsôsorban a holokausztemlékezet és a holokausztot reprezentáló magyar filmek sajátosságain keresztül közelít a két film értelmezési lehetôségeihez. A tanulmány középpontjában az áldozatok és a kollaboránsok traumatizáltsága áll, és arra keresi a választ, hogy miképpen jelenik meg e két identitás az említett filmekben. Az elemzés egyik célja az Akik maradtak optimizmusának részletes vizsgálata, valamint a különbözô emberi sorsok újrakezdési lehetôségeinek bemutatása Tóth Barnabás és Török Ferenc filmjén keresztül.

\section{Szerzó}

Dávid Réka Anna (2000) jelenleg az Eötvös Loránd Tudományegyetem másodéves magyar alapszakos hallgatója, minorként filmelméletet és filmtörténetet tanul. Interjúkat, és tudósításokat készít, ez az elsô publikált tanulmánya.

E-mail: rekaannadavid@gmail.com
\end{abstract}

https://doi.org/10.31176/apertura.2021.16.4.10 


\section{Dávid Réka Anna}

\section{Sorsváltozatok a jelenlétben. Az újrakezdés lehetôségei Tóth Barnabás Akik maradtak és Török Ferenc 1945 címú filmjében}

Az eufemizmus ellen: az emlékezet.

Hogy ne történhessen meg újra.

Valeria Luiselli [1]

\section{Bevezetés}

Napjainkban is évente jelennek meg a vészkorszakot tematizáló irodalmi, képzômúvészeti és filmmúvészeti alkotások, melyek folyamatosan formálják a jelen holokausztképét és emlékezetét, egyre növekvô tájékozódási alapot nyújtva az újabb generációk számára. Éppen ezért ott lebeg a kérdôjel is: Hogyan lehet, vagy inkább hogyan érdemes megragadni a huszadik század legsötétebb történelmi eseményét a Sorstalanság (Koltai Lajos, 2005), a Schindler listája (Steven Spielberg, 1994), vagy éppen a Saul fia (Nemes Jeles László, 2015) után? Tóth Barnabás munkája egy szokatlanul optimista hangvételú alkotás, mely a „post-witness”, vagyis a tanúk utáni korszak küszöbén a történelmi mélypont ábrázolása helyett a holokauszt utáni évtizedek életminôségére, az újrakezdés lehetôségeire fordítja a figyelmet; a túlélők friss, elfojtott, kibeszéletlen traumáit tematizálja, melyek az útkeresésben, majd a normalitáshoz való visszatalálásban oldódnak fel. Mindezt egyúttal a rendezó egy újabb tragikus történelmi folyamatba, a magyar kommunista diktatúra árnyékába helyezi. A múltfeldolgozás sajátosságainak kiemeléséhez Tóth filmjét Török Ferenc 1945 címú, tematikájában hasonló, megoldásaiban eltérô munkájával fogom összehasonlítani.

\section{Emlékezô identitás}

Az emlékezés a tudás és az identitás alakulásában is meghatározó szerepet tölt be, ezért egy olyan kiindulópont, ami felôl a múvészeti alkotások is érthetôbbé, átláthatóbbá válnak. Maurice Halbwachs ${ }^{[2]}$ tétele szerint az emlékezet az egyes ember „tulajdona”, az emlékezóképesség azonban kollektív produktum. Az ember másokhoz képest emlékezik, másokhoz képest határozza meg önmagát, saját sikereit mások kudarcaihoz mérten könyveli el. Az emlékezés az ember alaptermészetének a része, a saját és rokonaink emlékei alapvető feltételek az identitásunk 
kialakításában. Az idôsebb generációkban feldolgozatlanul maradt és elhallgatott traumák tovább öröklődhetnek. „Szüleink, nagyszüleink, soha nem látott ôseink tapasztalatai, élményei, félelmei és szenvedései súlyos örökségként befolyásolják sorsunk alakulását." [3] Mindez a

holokausztemlékezet vizsgálatakor azért nélkülözhetetlen tényezô, mert a túlélốk utódjainak mindennapjait meghatározza a felmenôik életében bekövetkező végzetes történelmi esemény: a saját identitástudatuk kialakítása nem lehetséges a családtörténetük megismerése nélkül. ${ }^{[4]} \mathrm{Ez}$ a gondolat köszön vissza a holokauszttúlélô Edith Eva Eger nemrégiben megjelent $A$ döntés címú könyvében is: „Mintha az identitásomat nem az határozná meg, hogy én ki vagyok, és mi van a birtokomban, hanem csak az jelölné ki, hogy a szüleimnek mi hiányzik." [5] A feldolgozatlan traumákkal nem csak a túlélôk, hanem az elkövetôk leszármazottainak is meg kell küzdeniük: „nem csak az áldozatszerep válik elkerülhetetlenné, de generációkon keresztül lehetetlenné válik az elkövetô szereptôl történő megszabadulás is." [6]

Jan Assmann fogalmazza meg, hogy az emlékezés az el nem felejthetô dolgokra összpontosul. [7] Az emlékezet szelektál, a múltat nem teljes egészében, képkockáról képkockára ôrzi, hanem a mindenkori jelen társadalmi keretei között rekonstruálja; azt ôrzi meg, ami a jövốben hasznosítható tapasztalatnak bizonyul. ${ }^{[8]}$ Emiatt a töredékjelleg miatt sem tehetünk egyenlőségjelet tény és emlék, esemény és emlékezet közé. Az emlékek az idô elörehaladtával változnak, amíg az emlékezôközösség életben tartja ôket. A holokauszt kapcsán ez a töredékjelleg azért is lényeges, mert minden élményszerú tudásunk a túlélốk emlékdarabjaiból származik. A jövôképüktôl és céljaiktól megfosztott emberek emlékeibôl egységes narratíva létrehozása nem lehetséges, ${ }^{[9]}$ így egy-egy alkotás is csak részlet tud lenni.

„Emlékezetközössége történelmi cselekvôkből, áldozatokból és szemlélókből áll” - írja Aleida Assmann egy tanulmányában, ${ }^{[10]}$ amelyben azt vizsgálja, hogy hogyan vált a holokauszt a globális emlékezet részévé. A haláltáborok megszervezése ugyan német kezdeményezéssel indult, de számos más nemzet is bûnrészes volt a kivitelezésükben. Különbözố nemzetiségek milliói estek áldozatul a népirtásnak, a túléloók és az áldozatok családjai pedig egy élhetôbb élet reményében új otthont kerestek maguknak az öt kontinens valamelyikén. Így a holokauszt lassan, de számottevően csak pár évtizeddel késôbb, az 1990-es évektôl vált a globális emlékezet részévé. Ezzel szorosan összefüggenek a közép-kelet-európai régiókban végbemenố rendszerváltások, melyek eredményeként gyökeresen megváltozott a társadalom emlékezethez és múlthoz való viszonya: „1989 után felszabadulnak a tabutémák.” [11] Ez nem csak a holokausztról, hanem a kommunizmusról való immár nyílt diskurzusnak is teret adott: „A kollektív emlékezet különböző és egymással versengó áldozati közösségei, a holokauszt és a kommunizmus elszenvedôi egyaránt láthatóságot akartak, olykor egymás ellenében. Megosztott és nem egymást segítô emlékezetek alakultak ki, amit a politika tovább gerjesztett." [12]

Napjainkban a modern technológiák bizonyos szempontból egyre több teret adnak a felejtésnek, hiszen egyes részinformációk megjegyzése elegendô az összkép visszakereshetôségéhez. Olykor még részinformációkra sincs szükség, ilyen-olyan módon emlékeztetve vagyunk. Az aktív emlékezés egyre inkább a háttérbe szorul, ezzel párhuzamosan pedig jelentôsen átalakul a 
képzelet jellege is: amit nem szükséges megjegyezni, az a képzeletünkben is elhalványul. Mindezt azért tartom fontosnak, mert mindkét tényezô meghatározó szerepet tölt be a múalkotások létrejöttében, melyek valamilyen módon visszacsatolnak a múlt eseményeihez, reflektál(hat)nak társadalmi kérdésekre, így magát az emlékezetet is életben tartják, vagy éppen formálják. A Marianna Hirsch által megfogalmazott „utóemlékezet” (post-memory) korszakában a holokausztot tematizáló múvészeti produktumok szerepe nem az összkép továbbítása, hanem leginkább az emlékeztetés ${ }^{[13]}$ és az (ön)reflexió. Ahogy Heller Ágnes írja: „A múvészi ábrázolásnak többet kell mondania annál, amit ábrázol. Valami újat, valami mást. Ez Auschwitz esetében lehetetlen. [...] Igaz, Auschwitzot is lehet reprezentálni. [...] A reprezentáció azonban emlékeztet a valóságra, életben tartja az emlékezetet." [14] A reprezentáció során a kortárs múvészetnek fontos szerepe van a sztereotípiákkal való szakításban, a korábbi álláspontok és narratívák tartalmi és formai újra értelmezésében, a párbeszéd megteremtésében és fenntartásában, „az emlékezet dekolonizálásában”. [15]

A „post-witness” korszak kezdetén, a szemtanúk generációjának eltúnésével az egyik legnagyobb kihívás a hiteles holokausztemlékezet életben tartása, annak a jelenkori politikáról való leválasztása és a diskurzus megalapozása az újabb generációk körében, mely kihívás egyúttal utat is nyit az új reprezentációs módok felé. ${ }^{[16]}$ Ugyanakkor nem csak a felejtés, hanem a globalizációból eredeztethetô általánosítás, a különbözố nemzetek emlékezetének az összemosódása is veszélyeztetheti a holokauszt emlékezetét, ezért ahogy Aleida Assmann is fogalmaz: „egy egységes, nemzeteket átívelő holokauszt-emlékezet kierôszakolása helyett inkább különböző önkritikus nemzeti emlékezetekre van szükség”. [17]

\section{Jelenlétváltozatok: magyar filmek a holokausztról}

A holokausztra sokszor mint „történelmen kívül esô határeseményre” hivatkozunk, mely felfoghatatlan, elképzelhetetlen és ábrázolhatatlan. Mégis minden szörnyúség, amit az ember a valódi életben elkövet, feljogosít, hogy versbe, regénybe vagy éppen filmre írjuk a valóságot. Az azonban már az alkotó felelôssége, hogy a médium és az ábrázolhatóság határainak figyelembe vételével, az esztétikai és etikai problémákat áthidalva, a megfelelő beszédmód és perspektíva kiválasztásával hiteles múalkotást hozzon létre. Csendben maradni vagy beszélni róla: a vészkorszak utáni újrakezdés dilemmája ez. ${ }^{[18]}$ Az elsô holokausztfilm megszületésével pedig a fókusz egyre inkább az ábrázolás mikéntjére helyezôdik át: hogyan lehet átadni a holokauszt emlékezetét az újabb generációknak? Miként volt és van jelen a zsidó tematika a különbözô korszakok magyar filmmúvészetében?

„Milyen undorító ez a világ! És különösen a mi számunkra. Megszólal egy fiatal nô: Hiszen olyan fiatal vagyok! Hiszen nem élveztem még az életből semmit, miért jár nekem ilyen halál? Miért?” A fenti idézet Nádasdy László 1964-ben készült Éva A5116 címú dokumentumfilmjének bevezetôjében hangzik el, a deportálásról és a haláltáborokról készült archív fényképsorozat narrációjaként. Nádasdy dokumentumfilmje kiemelkedő alkotás, a különböző beszédmódok és 
múfajok ötvözése a kommunista Magyarországon különösen modernnek hat, melynek közvetett folytatása csak egy évtizeddel késôbb, a Budapesti Iskola irányzatában összpontosul. ${ }^{[19]}$ A filmben Éva Krcs, akit a háború után egy lengyel család fogadott örökbe, hazalátogat Magyarországra, hogy megkeresse vérszerinti rokonait. Az újságban megjelenô hirdetésre az ország minden részérôl akadnak jelentkezôk, akik a lányban rég elveszett rokonuk hazatérését vélik felfedezni. Ezáltal a film egyszerre szól Éva identitáskeresésérôl és a veszteségeket szenvedett szülô, nagyszülô generáció traumáinak feldolgozatlanságáról. A film azok portréja, akik maradtak, jelenlétük dokumentálása tovább hordozza a holokauszt emlékezetét.

Két évtizeddel késôbb hasonló módszert választ Gazdag Gyula is, Társasutazás (1985) címú filmjének elkészítésekor, melynek során egy utazási iroda által szervezett auschwitzi utat dokumentál. A kamera megfigyelôként van jelen, a társasutazás résztvevôi és az arcát nem vállaló holokauszttúlélô nô felidézett emlékei között ingázik. A film látványvilága annyit mutat meg, amennyit a társasutazás résztvevôi maguk is láttak, ${ }^{[20]}$ amennyi a jelenlétükbôl megmutatható. A visszatérés, a belsô utazás elengedhetetlen lépés a gyógyulás útján, a traumák feldolgozásának folyamatát azonban már nem közvetíti a film.

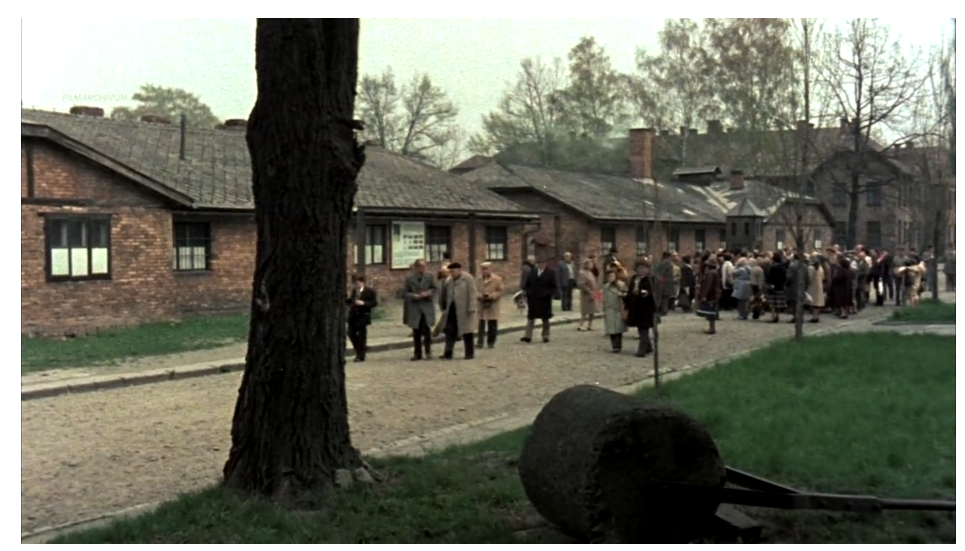

Társasutazás (Gazdag Gyula, 1985)

A holokausztot reprezentáló regényekben és játékfilmekben gyakori elem az események gyerekvagy kamaszszemszögból való elbeszélése. A gyerekek által észlelt valóság egyszerre iszonyú és érzékletes: annyira valóságosnak hat, hogy már fikciónak tûnik. ${ }^{[21]} \mathrm{Ez}$ a fajta szemszög szimbolikus, úgy távolít el, hogy mégis közel marad: a gyerekszem érzékeli a körülötte folyó káoszt és fenyegetettséget, de érteni, felfogni nem képes. ${ }^{[22]}$ Jeles András 1993-ban készült Senkiföldje címú filmjében Éva, a tizenhárom éves zsidó kislány történetét követjük végig. Sok minden kimondásra kerül már a film elején: „Különben nem nagyon örülök mostanában a születésnapomnak, mert tavaly a születésnapomról vitték el a Münzer Mártát, az unokatestvéremet a csendőrök" - megrázó mondatok ezek egy tizenhárom éves kamaszlány naplójából. A szubjektív gyermeki szemszög jelenik meg a Gyöngyössy Imre és Kabay Barna rendezésében készült Jób lázadása (1983) címú filmben is, mely a vidéki zsidóság deportálás elôtti, 1943-as évére helyezi a hangsúlyt. A gyermeki nézôpont azért is hatékony, mert nem kezdettôl fogva adott: a zsidó házaspár örökbefogadott gyermeke, Lackó a falusi életbe való beilleszkedéssel és az idô elôrehaladtával válik a film fôszereplôjévé. A rendezôk elegánsan kerülik el a túlzásokat, a 
dedramatizálás és a lírai atmoszféra összhangban van Lackó szemszögével, [23] aki egyszerre aktív és passzív szereplôje a filmnek. Aktív, mert eleinte mindent megtesz annak érdekében, hogy felbosszantsa új szüleit, majd pedig, hogy megakadályozza deportálásukat. És passzív, mert kívülálló, nem résztvevôje, „csak” szemlélôje az izraelita szertartásoknak és az ốt körülvevô zsidó kultúrának.

A rendszerváltás következtében felszabaduló tabutémák, a holokausztemlékezet globálissá válása és az eltelt 40-50 év minőségi változást eredményezett a filmgyártásban: „ekkor már eltávolodunk annyira az adott eseménytôl, hogy a róla való beszéd is átalakul." ${ }^{[24]} \mathrm{Ez}$ pedig elvezet minket a kortárs filmmúvészethez. A kilencvenes években meginduló folyamat elôkészítette az elmúlt évek egyik legfontosabb holokausztfilmjét, a Saul fiát. Nemes Jeles László szakít a konvencionális ábrázolási módokkal, és kísérletet tesz arra, hogy egy új filmnyelv, a képszúkítés elvének segítségével átélhetôvé tegye a haláltáborok klausztrofób világát. [25]

A filmek egy része tehát a személyes élettörténeteket helyezi előtérbe, míg más filmek a kollektivitásra helyezik a hangsúlyt. Ez a két megközelítés figyelhetô meg Tóth Barnabás és Török Ferenc filmjében is.

\section{A fikció optimizmusa}

A holokausztemlékezet és a reprezentáció sajátosságainak áttekintése után tanulmányomat Tóth Barnabás filmjével folytatom. Igyekszem minél pontosabb elemzést adni az emlékezés és az ábrázolás módjáról, a film újszerúségérôl és a kortárs posztholokausztot reprezentáló filmekhez való viszonyáról.

A történet során egy kamaszlány, Wiener Klára és egy középkorú férfi, Körner Aladár egymásra találását követjük végig, akik a második világháborúban elszenvedett veszteségek és tragédiák után, egy újabb diktatúra kezdetén együtt indulnak el a feldolgozás útján. 1945 és 1949 között a világháborúról való nyilvános beszédben a civil-, katonai és zsidó áldozatokról való megemlékezés a gyốztes Szovjetunió által uralt Magyarországon tabutémának számított. [26] „A jelenben tehát ugyanúgy kellett rettegni és titkolózni, ahogy a közelmúltban is" [27] - nyilatkozta egy interjúban F. Várkonyi Zsuzsa a film alapjául szolgáló Férfiidók lányregénye címú könyv szerzōje. Ebben a reményvesztett korszakban, az 1948-as év félelemmel teli atmoszférájában kezdôdik Tóth Barnabás filmje, az Akik maradtak (2019).

Klára és Aldó szinte ellenpólusai egymásnak. Klára gyerekként, Aldó szülöként veszítette el a családját, amit most mindketten a másikban vélnek megtalálni. A generációs, nemi és személyiségbeli különbségek e két egymástól meglehetôsen eltérô identitás megküzdési stratégiáit hangsúlyozzák. A holokauszt Szabó István Álmodozások kora (1965), Herskó János Párbeszéd (1963) vagy Gárdos Péter Hajnali láz (2015) címú filmjéhez hasonlóan „nyelven túli határeseményként” rejtjelezve jelenik meg, de már a film legelején ott van Klára tagadásában: „Nem volt! Él, csak még nem tudott hazajönni.” A holokausztról való nyílt beszéd kerülése és a szereplôk gesztusokon, 
félmondatokon keresztül történố kommunikációja nem csak a színészi játékot, hanem a film formanyelvét is meghatározza. A gesztusok és félmondatok úgy beszélnek a holokausztról, „hogy - a szó szoros értelmében - szó sem esik róla." ${ }^{[28]}$ Az Almodozások kora egy nemzedéki közérzetfilm, mely a trilógia másik két részével (Apa [1966], Szerelmesfilm [1970]) együtt, de önmagában is egy komplexebb képet ad a korszak fiatal felnôtt generációjáról. Az Akik maradtak nem azt mutatja meg, hogy általában véve milyen volt az ötvenes években élni - a történelmi tapasztalat vizuálisan sem tolakszik a személyes dráma elôterébe ${ }^{[29]}$ - hanem azt, hogy két traumatizált karakter hogyan boldogulhatott egy újabb diktatúra kezdetén.

A feldolgozatlan traumák miatt Klára eleinte csak jelen idóben tud beszélni a családjáról. Még leveleket is ír a szüleinek, amelyekben beszámol nekik Aldóról és a városban zajló eseményekrôl, mintha azok, akik elmentek, bármelyik pillanatban visszatérhetnének. Aldó megpróbál szembenézni a múlttal, és magától elindulni a feldolgozás útján; gyakran ellátogat az izraelita hitközösség árvaházába, még játékokat is adományoz a gyerekeknek, de valójában Klára kell ahhoz, hogy kizökkenjen ebból a rutinszerú, repetitív életmódból. Jancsó Jelenlét-trilógiájában az emlékezet nem a szubjektumban, hanem sírkövekben, falakban és romos zsinagógákban él, ${ }^{[30]} \mathrm{az}$ Akik maradtak-ban az elhunyt családtagok Klára és Aldó emlékezetében a hiányukkal vannak jelen. Miközben egyre közelebb kerülnek egymáshoz, Klárában lassan feloldódnak az elfojtott traumák, és amennyire lehetséges, elfogadja, hogy sosem fogja viszont látni a családját. A lassú folyamat közben mindkét karakterben előhívódnak az „azelôtti” emlékek. Ilyen például az a jelenet, amikor Aldó vizet melegít Klárának, aki szemét lehunyva felidézi, amikor húgának egy ugyanilyen fürdôkádban ülve az ismert Én elmentem a vásárba... kezdetû népdalt énekelte. Egy másik jelenetben Klára Aldó fényképalbumának a nézegetése közben szembesül a férfi múltjával, mely felszínre hozza a lányban egy idillikus családi pillanat emlékét. A fájdalom mellett az emlékezés a továbblépés lehetôségét is magában hordozza, például abban a jelenetben, amikor Klára Aldót nézi borotválkozás közben, és eszébe jut egy emlékkép, amikor apja játékosan összekente borotvahabbal az ô orrát, majd pár másodperccel késôbb visszatérünk a jelenbe, és a tükörbôl újra Aldó néz vissza rá. A jelen eseményei indikátorokként múködnek, összekötik a múltat a jelennel, ahogy a hiány helyét fokozatosan begyógyítja egy új élet lehetôsége.

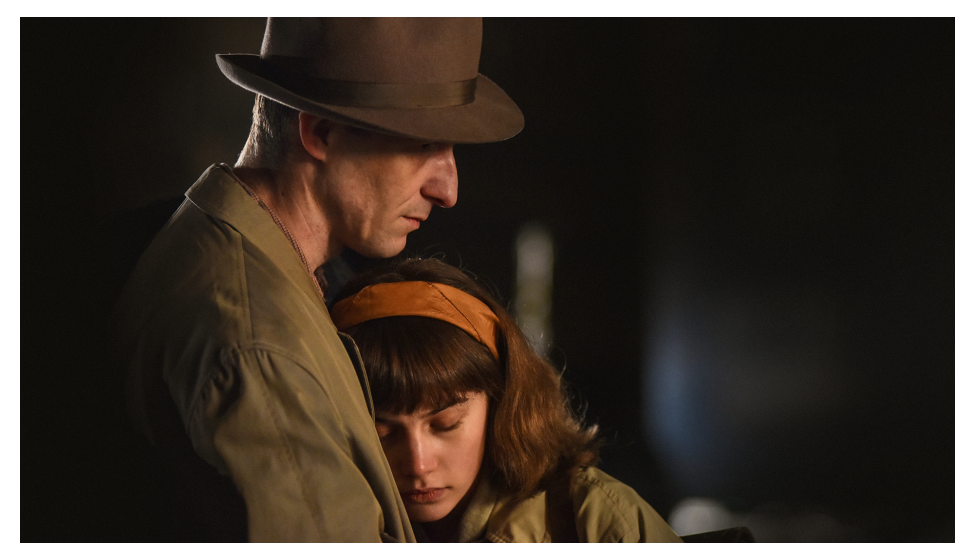

Akik maradtak (Tóth Barnabás, 2019)

Némi leegyszerúsítéssel az Akik maradtak a holokausztról szóló filmek azon csoportjához 
sorolható, amelyek az ábrázolhatatlanság elvéből kiindulva közelítenek a megjelenítés felé, [31] ugyanakkor eltér azok koncepciójától azáltal, hogy Tóth Barnabás a regény tematikus döntését felhasználva nem a koncentrációs táborokra, hanem a gyógyulás folyamatára helyezi a hangsúlyt. Ezért a rendezố nem is törekszik arra, hogy a Saul fiához hasonlóan kísérletet tegyen az „ábrázolhatatlan holokauszt” és az „átélhetôvé tehetô holokauszt” közötti ellentét áthidalására. [32] „Mindig az van, hogy megjelennek a szörnyú nácik, aztán késôbb jön a vonat, a tábor. [...] Engem nem ez érdekelt, hanem a »szép emberi«, a gyógyítás, a traumafeldolgozás, az, hogy adjon valami pici vigasztalást vagy erốt azoknak, akik bármilyen traumán estek túl” - nyilatkozta a rendezô egy sokat idézett interjúban. ${ }^{[33]}$ Az Akik maradtak újító jellege tehát abban rejlik, hogy a középpontban a traumatizált szereplôk gyászmunkája és a normalitáshoz való visszatalálás áll.

„Engem egyszerúen itt felejtettek” - jelenti ki Klára a film elsô harmadában. A címet dialógusként halljuk viszont. A „maradtak” szó gazdag jelentéstartalommal bír, nem csak a zsidó kisebbség, hanem a magyarok számára is: „a történelem során a magyar ember mindig ezt látja, ezt érzi, ezt hallja, ezt érinti, errôl ír, errôl készít filmet, errôl beszél a patikában is: maradtunk." [34] Hasonló elnevezést használt Jancsó Miklós is a Kövek üzenete címú dokumentumfilm-sorozatának Gheorghe Covaciról és Friedmann Mendelról szóló második részében, mely Maradékok címmel jelent meg 1993-ban. A „maradék” szó nem csak valamely élő vagy élettelen csoport eltûnôben lévô részét jelöli, hanem utódot, leszármazottat is jelent, ami pedig magában hordozza a további élet

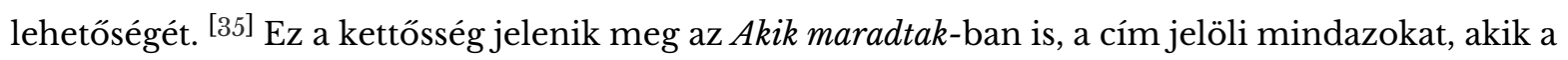
holokausztban elveszítették a családjukat, akik azt gondolják, hogy óket egyszerúen itt felejtették, hogy ôk jártak rosszabbul, de azokat is, akik igent mondanak az életre.

\section{Társak az emlékezésben}

Tóth Barnabás adaptációját több szempontból is érdemes összevetni Török Ferenc 1945 címú filmjével. A közös vonások ellenére a két alkotás merôben eltérô irányból közelíti meg a posztholokauszt témáját; míg az Akik maradtak két zsidó származású szereplô személyes történetét meséli el, az 1945 rendszerkritikus alkotás, az ideológiának áldozatul esett magyar

kollaboránsokról, a múltbéli búnökról és a búntudat erejérôl szól. A holokauszt egyik filmben sem elhanyagolható tényezô, de elsôsorban a motivációk és az okok megértéséhez szükséges. ${ }^{[36]}$ Mindkét film irodalmi alapanyaggal dolgozik: Tóth Barnabás a már említett Férfiidók lányregényét, Török Ferenc Szántó T. Gábor Hazatérés címú elbeszélését adaptálta. Irodalmi múvek adaptálása a magyar filmtörténetben kezdettól fogva létezố gyakorlat, a holokausztfilmek között mégis ritkább tendencia. Ennek egyik oka lehet a dokumentumfilmes megközelítés gyakorisága a

holokausztreprezentációban, mely többek álláspontja szerint a hiteles közvetítés legkézenfekvôbb módja: ${ }^{[37]}$ a felejtésre ítélt tabutémák feldolgozásában a dokumentumfilm „hol egy lépéssel megelôzi, hol közvetlenül elôkészíti a játékfilmes feldolgozást”. [38]

Az 1945 nem sokkal a háború után, egy északkelet-magyarországi faluban játszódik, melyet a rendezô szándékosan nem nevez meg; azt sugallja, hogy a drámai események az akkori 
Magyarországon bárhol megtörténhettek volna. ${ }^{[39]}$ A sok megpróbáltatás után a faluban látszólag nyugalom és béke honol; a lakók esküvôre készülődnek, amikor láncreakcióként kezd terjedni a hír: két zsidó érkezett a faluba, ráadásul nagy ládákat hoztak.

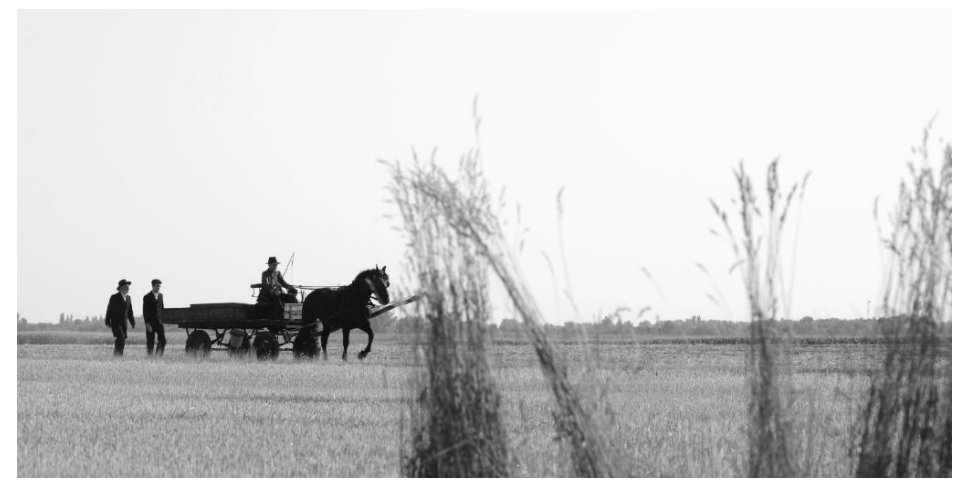

1945 (Török Ferenc, 2017)

A történelmi háttér adott, így érvényes mindaz, ami az Akik maradtak kapcsán is: a „felejtés politikája” és a „szembenézés elutasítása”. ${ }^{40]}$ Az államszocializmusban továbbra is hallgatni kellett a holokausztról, amihez a magyar vidéken a feudális hagyomány és a gazdasági, kulturális elmaradottság társult. ${ }^{[41]}$ Ilyen körülmények között „[a] hazatérés természetesen illúzió: a lélek egy része biztosan ott marad, ahol a szörnyúségek megtörténtek. A nagyobb kérdés inkább az, ha lehet is tovább élni, milyen minôségú lesz ez az élet. A múltat nem lehet eltörölni, és ez sok tekintetben a jövôt is lehetetlenné teszi.” ${ }^{[42]}$ Török és Tóth filmjében az áldozatok és az elkövetôk sorsának alakulásában is egyaránt kulcskérdés: mit kezdenek a bennük lüktetô múlt sebével a jelenben? Klárát és Aldót a sorstársiasság és az ebbôl fejlôdô intimitás egy jobb élet felé segíti, míg az 1945-ben egy negatívabb képet kapunk: a két zsidó érkezése pillanatok alatt felébreszti a falusiak lelkében szunnyadó búntudatot, akik a végsôkig bizonygatják jogosságukat a hazug módon szerzett tulajdonok felett. „A szembesítés elkerülhetetlen - a szembenézést azonban könnyen ki lehet cselezni." [43] A fullasztó légkörből csupán egyetlen szereplö, a jegyzó fia tud elmenekülni. A többiek vasvillákkal a kezükben, megsemmisülve nézik a két zsidó távozását, a feljelentố levelet író Kustár András egyetlen kiútként az öngyilkosságot választja. 
Az 1945 sokszereplős dráma, középpontban a falu jegyzőjével, Szentes Istvánnal, aki az ármánykodás útján szerzett javak legnagyobb haszonélvezôje. A jegyző fia, Szentes Árpád, menyasszonya Kisrózsi és a kommunista eszmékkel szimpatizáló Jancsi képviselik a szüleiktôl eltávolodó újabb generációt. A térben elkülönített szereplôk a film felénél találkoznak: a falusiak gyanúsan méregetik a szekéren érkező zsidókat. Ezután ismét szétválnak, az események párhuzamosan zajlanak tovább, majd legközelebb a film tetôpontján, a temetônél érnek össze. A láda McGuffinként múködik, nem az a lényeg, hogy mit tartalmaz - „ládákat hoztak illatszerekkel” -, hanem hogy milyen tapasztalatot ébreszt, és milyen reakciókat vált ki a közösségben. Abûntudat ezen tapasztalata gúzsba köti és felemészti a szereplóket, a folytatás kérdésessé válik, agyógyulás lehetôségére már nem tér ki a film. Az elkövetốk és a kollaboránsok megtanulnakegyütt élni a búneikkel, legfốbb motivációjuk, hogy a jelen távlatából is bebizonyítsák: ártatlanok.A búnbánat és a bocsánatkérés szintjére nem mindenki jut el, így a megbékélés sem lehetséges. [44]

Paweł Pawlikowski Ida (2013) címú posztholokauszt-filmjében hasonló indulatokat vált ki Feliksbool a bûntudat; eleinte tagadja, hogy valaha zsidók éltek itt, a cselekmény elôrehaladtával, késôbb ismeri csak be, hogy ő a felelôs Ida családjának a haláláért. A kiásott sírhelyben kuporgó, fejét lehajtó ember a megbánás ikonikus képévé válik.

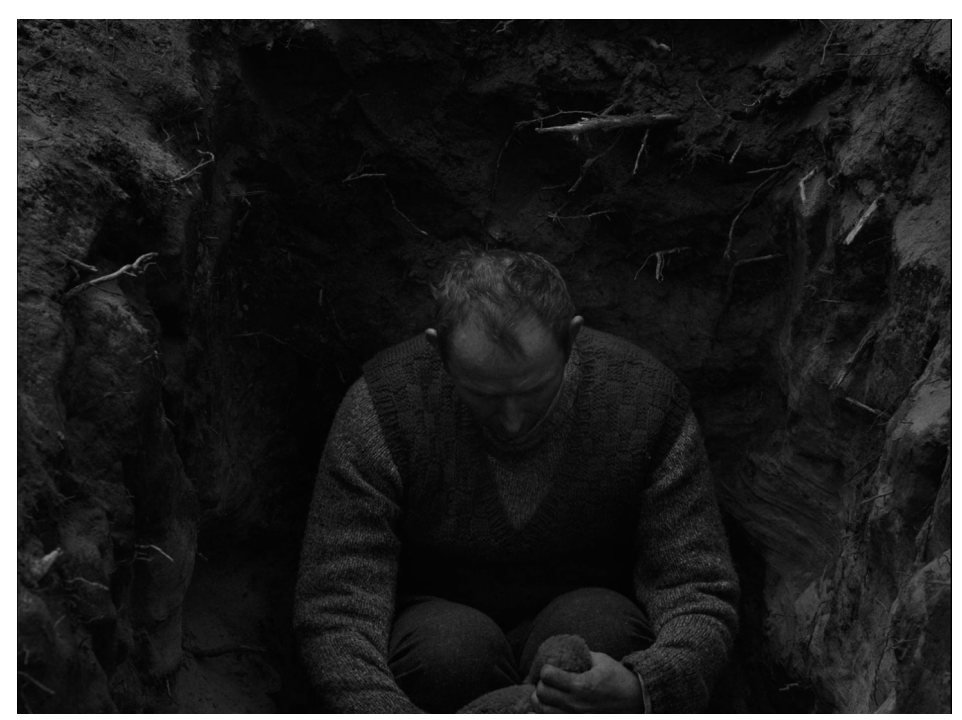

Ida (Pawet Pawlikowski, 2013)

Az Akik maradtak lineáris cselekményébe beékelődnek Klára látomásszerú flashbackjei ('igy építi be a rendezô a „lányregény” múfajt, és így válik a film felnövéstörténetté), de Aldó reményvesztett tekintetében is visszatükröződik az emlékezés fájdalma. A két, kapcsolódásra vágyó fôszereplô elóéletérôl csak annyit tudunk meg, amennyi a jelen megértéséhez szükséges. A kamaszlány és a középkorú férfi elsô kapcsolódása a fizikain, a megfoghatón keresztül történik: a test, a nôvé válás és a szexualitás sajátosan árnyalt feszültséget ad a filmnek, melyet késóbb homályban hagy a rendezô. Az ávósok és az elhurcolástól való rettegés ugyan erôs szexuális töltetet ad az ölelkezésüknek, de késôbb nem tisztázódik a két fél viszonya. A cselekmény ambivalens lezárása, a kibontatlan vonzalom hiányérzetet kelt. Mintha a szexualitás csak késôbb került volna bele egy 
már készülőfélben lévố történetbe, aminek nem tudott a szerves részévé válni.

Mindkét film kerüli a közhelyeket és az életbölcsességeket, egyikük sem mond ítéletet, nem kínálják az élethelyzetek egyszerú megoldását. Az Akik maradtak egy kifejezetten optimista hangvételú alkotás, a továbblépés lehetôségével. A megbékélés és az integráció csakis az áldozati identitás elengedésével lehetséges. ${ }^{[45]}$ Az 1945 nem csak azért mérföldkő a magyar filmtörténetben, mert szembesít a magyar zsidóság 20. századi tragédiájával, mely a vidéki zsidóság legnagyobb részének kiirtásával végződött, ${ }^{[46]}$ hanem azért is, mert fontos szerepet játszik a kurrens holokausztemlékezetben azáltal, hogy elhatárolja magát az általánosító, sematikus megoldásoktól, és helyette a (már Aleida Assmann kapcsán említett) történészek és pedagógusok által javasolt önkritikus nemzeti emlékezetet erôsítô alkotást hoz létre.

A filmek látványvilága meglehetôsen különbözik egymástól. Az Akik maradtak formanyelve egyszerú; statikus beállítások, lassú kameramozgások és közelképek dominanciája jellemzi a filmet, színvilágában a tompa, meleg, ôszi színek donimálnak. Ebben a megközelítésben hangsúlyos szerepet kapnak a gesztusok, érintések és a félmondatok, ami elegendô idôt hagy a szereplókkel való azonosulásra és a visszafogottság, lírai atmoszféra érzetét kelt(het)i. Az 1945 fekete-fehér színvilága, letisztult kompozíciói és belsô keretei, a díszletek kidolgozottsága és gazdag hangvilága összetettebb és tudatosabb formanyelvet eredményez. Ez a megközelítés alaposan átgondolt megoldás, itt nincsenek féligazságok és feleslegesen elnyújtott dialógusok, a hangsúly fokozatosan a tagadás terhére kerül. A film kiválóan használja a különbözô zörejek és hangok atmoszférateremtố jellegét, az órakattogás, a templomharang és a lovak patájának visszatérô dobogása feszültséget teremt; az idô megállíthatatlanul halad egy elkerülhetetlen katasztrófa felé.

Érdemes összehasonlítani az elhallgatások szerepét a két filmben. Az Akik maradtak-ban egyrészt bizonytalanná teszik a két fôszereplô viszonyának a megítélését, másrészt hangsúlyozzák a traumák kibeszéletlenségét. Az 1945-ben a dramaturgia és a színészi játék szerves részét képezi a csend és a szereplôk elhallgatása. Kiemelik a belsố dilemmákat, a bûntudat felszínre törését és a fékezhetetlen idôt, amely cselekvésre készteti ôket. Ez erôsíti az 1945 központi drámai feszültségét; az idôbeli és a térbeli kötöttséget.

Török filmje sokféle egyéni sorson keresztül próbálja megragadni a történelmi korszak közösségi hangulatát. Ismert archetípusokon keresztül (hatalmi fölénnyel visszaéló jegyzô, szerelmi háromszög, férjét irányító feleség stb.) szembesít az emberi viselkedésformák jelen esetben meglehetôsen tragikus voltával. A sokszereplôs dráma széltében-hosszában növekvô feszültséghálója egyre kevésbé bírja el a falu hallgatását, a végsố robbanás nem a semmiból jön, alaposan felépített jelenetek elôzik meg: egymásnak feszülő pillantások, fenyegetések és titkos szóváltások készítik elô a lelkiismeret önmagán vett elégtételét. Tóth nagyvárosi környezetben játszódó filmjében a közösségi létforma és annak sajátos feszültségei kevésbé hangsúlyosak, a rendezố inkább a hasonló traumákkal küzdô személyes életutak találkozását és ennek gyógyító erejét helyezi elôtérbe. Az 1945 szereplôi számára az újrakezdés lehetôsége kétséges, legtöbbjük 
kudarcot vall a bưntudattal való harcban. Az emlékezô közösség számára megnehezíti a továbblépést, hogy társak voltak a zsidók feladásában és kifosztásában, így társak a tagadásban is. A felejteni kívánt emlékek kollektív produktumok, melyek súlyát csak egymással megosztva tudták valamelyest elviselhetố tenni. Amikor azonban a két zsidó leszáll a vonatállomáson, repedezni kezd, és végül porig ég a hónapokig építgetett hazugságfal, amely a falu kapcsolatrendszerét is magával temeti.

Az Akik maradtak-ban az egyéni emlékezetek találnak közösségre egymásban. Aldó és Klára az első találkozástól fogva érzik egymás szenvedéstôl terhes múltját, mintha a magány és a feldolgozás igénye finoman egymáshoz terelné ôket. Klára karakterében felismerhetô a holokausztot reprezentáló filmekben gyakran alkalmazott gyerek- vagy kamaszperspektíva, amely egy felnövéstörténetet is bevezet. Nyers, szókimondó jelleme és a valóságra való érzékenysége a Senkiföldje Évájához hasonlóan megdöbbentố egy tizenhat éves lány szájából. A posztholokauszt dokumentumfilmek archív fényképeit, az eredeti helyszínekre való visszatérést, a keserû visszaemlékezéseket az Akik maradtak-ban a fikció megrendezett képi világa és optimizmusa váltja fel. A valóságban évtizedekig vagy sokszor örökké tartó küzdés a múlttal a filmben mintha pár évben tömörülne össze; az utolsó elótti jelenetben idillikus családi ebédet látunk, a jelenet színvilága is világosabbá, derúsebbé válik, ugyanakkor Aldó és Klára tekintete, Aldó testtartása és a fürdőszobaajtónál történő rövid dialógus továbbra is hordozza az elfelejthetetlen traumák emlékét. A szereplôk útja a magánytól a normalitás felé vezet. A rendezô az egyéni sorsok finom rezdülésein és konfliktusain keresztül veti fel a lehetôséget: az újrakezdés is egy lehetséges életút a megrázó események után.

\section{Jegyzetek}

1. Valeria Luiselli: Elveszett gyerekek archívuma. Budapest, Magvetô Kiadó, 2020.

2. Halbwachs, Maurice: Kollektív emlékezet. In Felkai Gábor - Némedi Dénes - Somlai Péter (szerk.): Szociológiai irányzatok a XX. század elejéig. Olvasókönyv a szociológia történetéhez. Budapest, Új Mandátum Kiadó, 2000. 403-432.

3. Orvos-Tóth Noémi: Örökölt sors. Budapest, Kulcslyuk Kiadó, 2018. 12-13.

4. Meleg Kristóf Ágoston: Társadalomutazás (Budapest - Auschwitz; Auschwitz - Budapest). Gazdag Gyula: Társasutazás. Filmkultúra, 2015. 01. 08. URL: http://www.filmkultura.hu/?q=cikkek/társadalomutazásgazdag-gyula-társasutazás

5. Edith Eva Eger: A döntés. Budapest, Libri Kiadó, 2017. 36.

6. Kovács Mónika: Kollektív emlékezet és holokausztmúlt. Budapest, Corvina Kiadó, 2016.

7. Assmann, Jan: A kulturális emlékezet. Írás, emlékezés és politikai identitás a korai magaskultúrában. Budapest, Atlantisz, 2004. 30.

8. Assmann, Jan: i.m. 41-43.

9. Pécsi Katalin: Elfojtott emlékek, Gondolatok Gazdag Gyula Társasutazás címú filmjérôl. In Surányi Vera (szerk.): Minarik, Sonnenschein és a többiek. Zsidó sorsok magyar filmen. Budapest, Magyar Zsidó Kulturális Egyesület, Szombat, 2015. 68- 69.

10. Aleida Assmann: A holokauszt - globális emlékezet? Egy új emlékezôközösség kiterjedtsége és korlátai. In Transznacionális politika és a holokauszt emlékezettörténete. Szerk. Szász Anna Lujza, Zombory Máté. 
Budapest, Befejezetlen Múlt Alapítvány, 2014. 182.

11. Turai Hedvig: Holokausztemlékezet a globalizáció korában. Ars Hungarica, 2017/4. 425.URL:

12. Turai Hedvig: i.m. 426.

13. Tordai Zádor szerint: „A tanulságokat sem lehet úgy összerakni, hogy abból magából értékelhetô összkép alakuljon ki. Lanzmann filmje is csak emlékeztetô tud lenni” (Tordai Zádor: Történelem és emlékezés határán. Shoah. Filmvilág, 1989/11.)

14. Heller Ágnes: A sors és a halál között nincs összefüggés. Senkiföldje - Jeles András filmje. In Surányi Vera (szerk.): Minarik, Sonnenschein és a többiek. Zsidó sorsok magyar filmen. Budapest, Magyar Zsidó Kulturális Egyesület, Szombat, 2015. 100.

15. Turai Hedvig: i.m. 428.

16. Margitházi Beja: Az érzékek felébresztése. Fotografikus traumanyomok és mediális emlékezetmunka (Saul fia, Regina, Varsói felkelés). Metropolis, 2018/1. 54.

17. Aleida Assmann: i.m. 170.

18. Pécsi Katalin: i.m. 64- 65 .

19. Vermes Dorka: Kihưlt helyek: Nádasdy László: Éva A5116. Filmkultúra, 2015. URL: http://www.filmkultura.hu/?q=cikkek/kihúlt-helyek-nádasy-lászló-éva-a5116

20. Pécsi Katalin: i.m. 69.

21. Heller Ágnes: i.m. 99.

22. Heller Ágnes: i.m. 99.

23. Benke Attila: A földi pokol gyerekszemmel. Jelenkor, 2020. 02. 08. URL:

24. Murai András: Képszúkítés, újrateremtés. Filmvilág, 2015. szeptember, 35-38. URL: https://www.filmvilag.hu/xereses_aktcikk_c.php?cikk_id=12379

25. Murai András: i.m.

26. Gyáni Gábor: A történelem mint emlék(mü). Budapest, Kalligram, 2016. 189.

27. Szalay Ágnes: Az Akik maradtak az egymásba kapaszkodás filmje - Interjú F. Várkonyi Zsuzsával, a film történetének szerzôjével. Dívány, 2019. szeptember 27. URL: https://divany.hu/eletem/2019/09/27/akikmaradtak/

28. K. Horváth Zsolt: Az emlékezés nulla fokán. Metropolis, 2001/03. URL: https://metropolis.org.hu/azemlekezes-nulla-fokan-1

29. Papp Attila Zsolt: „Miért kurva, aki fél egyedül?”- Tóth Barnabás: Akik maradtak. Filmtett, 2019. szeptember 23. URL: https://www.filmtett.ro/cikk/miert-kurva-aki-fel-egyedul-akik-maradtak-kritika/

30. K. Horváth Zsolt: i.m.

31. Murai András: i.m.

32. Murai András: i.m.

33. Balla István: Tóth Barnabás: Mindig az van, hogy megjelennek a szörnyú nácik, engem nem ez érdekelt. hvg.hu, 2019. szeptember 16. URL: https://hvg.hu/kultura/20190916_toth_barnabas_interju_akik_maradtak_oscar_dij

34. Karkó Ádám: Hazánkban élni: Tóth Barnabás Akik maradtak címú filmjérôl. Pannon tükör, 2020. $105-107$.

35. Czuczor Gergely - Fogarasi János: A magyar nyelv szótára 1-6. Pest/Budapest, Emich Gusztáv/Athenaeum, 1862-1874.

36. Papp Attila Zsolt: i.m.

37. Raczky Júlia: Múvirág, cigarettaszünet, fotó Auschwitzban - Gazdag Gyula: Társasutazás. Filmkultúra, 2015. január 8. URL: http://www.filmkultura.hu/?q=cikkek/múvirág-cigarettaszünet-fotó-auschwitzban-gazdag- 
gyula-társasutazás

38. Gelencsér Gábor: Kísért a múlt. Filmvilág, 2017/04, 50.

39. Hujbi: 1945 - Kritika. Hetedik sor közepe, 2017. április 21. URL: https://hetediksor.hu/2017/04/21/1945kritika/

40. Gelencsér Gábor: i.m.

41. Bartha Eszter: Szembenézés: 1945. Eszmélet, 2017/2. 195-200.

42. Gyôrffy Iván: Megtisztulás. Mozgó Világ, 2017. 07. 16. URL:

43. Győrffy Iván: i.m.

44. Kovács Mónika: i.m.

45. Kovács Mónika: i.m.

46. Bartha Eszter: i.m.

\section{Irodalomjegyzék}

- Assmann, Aleida: A holokauszt - globális emlékezet? Egy új emlékezőközösség kiterjedtsége és korlátai. In Transznacionális politika és a holokauszt emlékezettörténete. Szerk. Szász Anna Lujza, Zombory Máté. Budapest, Befejezetlen Múlt Alapítvány, 2014.

- Assmann, Jan: A kulturális emlékezet. Írás, emlékezés és politikai identitás a korai magaskultúrában. Budapest, Atlantisz, 2004.

- Balla István: Tóth Barnabás: Mindig az van, hogy megjelennek a szörnyú nácik, engem nem ez érdekelt. hvg.hu, 2019. szeptember 16. URL: https://hvg.hu/kultura/20190916_toth_barnabas_interju_akik_maradtak_oscar_dij

- Bartha Eszter: Szembenézés: 1945. Eszmélet, 2017/2. 195-200.

- Benke Attila: A földi pokol gyerekszemmel. Jelenkor, 2020. 02. 08. URL: http://www.jelenkor.net/visszhang/1605/a-foldi-pokol-gyerekszemmel

- Czuczor Gergely - Fogarasi János: A magyar nyelv szótára 1-6. Pest/Budapest, Emich Gusztáv/Athenaeum, 1862-1874.

- Eger, Edith Eva: A döntés. Budapest, Libri Kiadó, 2017.

- Gelencsér Gábor: Kísért a múlt. Filmvilág, 2017/04.

- Gyáni Gábor: A történelem mint emlék(mü). Budapest, Kalligram, 2016.

- Gyôrffy Iván: Megtisztulás. Mozgó Világ, 2017. 07. 16. URL: https://mozgovilag.hu/2017/07/16/gyorffy-ivan-megtisztulas/

- Halbwachs, Maurice: Kollektív emlékezet. In Felkai Gábor - Némedi Dénes - Somlai Péter (szerk.): Szociológiai irányzatok a XX. század elejéig. Olvasókönyv a szociológia történetéhez. Budapest, Új Mandátum Kiadó, 2000. 403-432.

- Heller Ágnes: A sors és a halál között nincs összefüggés. Senkiföldje - Jeles András filmje. In Surányi Vera (szerk.): Minarik, Sonnenschein és a többiek. Zsidó sorsok magyar filmen. Budapest, Magyar Zsidó Kulturális Egyesület, Szombat, 2015.

- Hujbi: 1945 - Kritika. Hetedik sor közepe, 2017. április 21. URL: https://hetediksor.hu/2017/04/21/1945-kritika/

3. Horváth Zsolt: Az emlékezés nulla fokán. Metropolis, 2001/03. URL: https://metropolis.org.hu/az-emlekezes-nulla-fokan-1 
- Karkó Ádám: Hazánkban élni: Tóth Barnabás Akik maradtak címú filmjéról. Pannon tükör, 2020. 105-107.

- Kovács Mónika: Kollektiv emlékezet és holokausztmúlt. Budapest, Corvina Kiadó, 2016.

- Luiselli, Valeria: Elveszett gyerekek archívuma. Budapest, Magvetô Kiadó, 2020.

- Margitházi Beja: Az érzékek felébresztése. Fotografikus traumanyomok és mediális emlékezetmunka (Saul fia, Regina, Varsói felkelés). Metropolis, 2018/1.

- Meleg Kristóf Ágoston: Társadalomutazás (Budapest - Auschwitz; Auschwitz - Budapest). Gazdag Gyula: Társasutazás. Filmkultúra, 2015. 01. 08. URL: http://www.filmkultura.hu/?q=cikkek/társadalomutazás-gazdag-gyula-társasutazás

- Murai András: Képszúkítés, újrateremtés. Filmvilág, 2015. szeptember, 35-38. URL: https://www.filmvilag.hu/xereses_aktcikk_c.php?cikk_id=12379

- Orvos-Tóth Noémi: Örökölt sors. Budapest, Kulcslyuk Kiadó, 2018.

- Papp Attila Zsolt: „Miért kurva, aki fél egyedül?”- Tóth Barnabás: Akik maradtak. Filmtett, 2019. szeptember 23. URL: https://www.filmtett.ro/cikk/miert-kurva-aki-fel-egyedul-akikmaradtak-kritika/

- Pécsi Katalin: Elfojtott emlékek, Gondolatok Gazdag Gyula Társasutazás címú filmjérôl. In Surányi Vera (szerk.): Minarik, Sonnenschein és a többiek. Zsidó sorsok magyar filmen. Budapest, Magyar Zsidó Kulturális Egyesület, Szombat, 2015.

- Raczky Júlia: Múvirág, cigarettaszünet, fotó Auschwitzban - Gazdag Gyula: Társasutazás. Filmkultúra, 2015. január 8. URL: http://www.filmkultura.hu/?q=cikkek/múvirágcigarettaszünet-fotó-auschwitzban-gazdag-gyula-társasutazás

- Szalay Ágnes: Az Akik maradtak az egymásba kapaszkodás filmje - Interjú F. Várkonyi Zsuzsával, a film történetének szerzôjével. Dívány, 2019. szeptember 27. URL: https://divany.hu/eletem/2019/09/27/akik-maradtak/

- Tordai Zádor: Történelem és emlékezés határán. Shoah. Filmvilág, 1989/11.)

- Turai Hedvig: Holokausztemlékezet a globalizáció korában. Ars Hungarica, 2017/4. 425.URL: https://fromfakemountainstofaith.eu/wpcontent/uploads/2020/05/EPA01615_ars_hungarica_2017_4.pdf

- Vermes Dorka: Kihúlt helyek: Nádasdy László: Éva A5116. Filmkultúra, 2015. URL: http://www.filmkultura.hu/?q=cikkek/kihúlt-helyek-nádasy-lászló-éva-a5116

\section{Filmográfia}

- 1945 (Török Ferenc, 2017)

- Akik maradtak (Tóth Barnabás, 2019)

- Álmodozások kora. Szabó István, 1964)

- Apa. (Szabó István, 1966)

- Szerelmesfilm (Szabó István, 1970)

- Éva A5116 (Nádasdy László, 1964)

- Hajnali láz (Gárdos Péter, 2014)

- Ida (Paweł Pawlikowski, 2013)

- Jelenlét (Jancsó Miklós, 1965) 
- Második jelenlét (Jancsó Miklós, 1976)

- Harmadik jelenlét (Jancsó Miklós, 1986)

- Jób lázadása (Gyöngyössy Imre és Kabay Barna, 1983)

- Kövek üzenete II.: Maradékok (Jancsó Miklós 1993)

- Maradékok (Jancsó Miklós, 1993)

- Párbeszéd (Herskó János, 1963)

- Saul fia (Nemes Jeles László, 2015)

- Schindler listája (Steven Spielberg, 1994)

- Senkiföldje (Jeles András, 1993)

- Sorstalanság (Koltai Lajos, 2005)

- Társasutazás (Gazdag Gyula, 1984) 
(c) Apertúra, 2021. nyár | www.apertura.hu

webcím: https://www.apertura.hu/2021/nyar/david-sorsvaltozatok-a-jelenletben-az-ujrakezdes-

lehetosegei-toth-barnabas-akik-maradtak-es-torok-ferenc-194.5-cimu-filmjeben/

https://doi.org/10.31176/apertura.2021.16.4.10

(Q) opertúro 